\begin{tabular}{c} 
Volume and Issues Obtainable at Center for Sustainability Research and Consultancy \\
Journal of Business and Social Review in Emerging Economies \\
ISSN: 2519-089X \& ISSN (E): 2519-0326 \\
Volume 7: Issue 4 December 2021 \\
CSRᄃ \\
Journal homepage: www.publishing.globalcsrc.org/jbsee \\
\hline
\end{tabular}

\title{
Realignment of Power Patterns in Indian Ocean: Role of Regional and Global Actors
}

*Muhammad Ijaz Latif, Chairman, Department of International Relations Islamia University of Bahawalpur

Muhammad Tayyab Zia, Associate Lecturer, Department of International Relations Islamia University of Bahawalpur

*Corresponding author's email: ijaz.latif@iub.edu.pk

\begin{tabular}{l} 
ARTICLEDETAILS \\
History \\
Revised format: Nov 2021 \\
Available Online: Dec 2021 \\
\hline Keywords \\
Indian Ocean, Indo- \\
Pacific, QUAD, \\
Gwadar, BRI
\end{tabular}

JEL Classification

F5, N4

\section{OPEN ? ACCESS}

ABSTRACT

Purpose: Purpose of study is to analyze the impact of changing strategic patterns and priorities of various regional and international actors on the Indian Ocean Region. Geo-political contestation for hegemony among these actors i.e. US, India, Japan, Australia, China and Pakistan is examined. Measures and counter-measures taken by the said states too are evaluated.

Design/Methodology/Approach: Analytical study based on qualitative descriptive analysis is formulated in inductive way.

Findings: Indian Ocean has been evolving to be the center-stage of Global power politics. US, UK, Australia, Japan and India are pursuing the goal of containment of China. China too has initiated economic partnerships with various states of the Indian Ocean Region i.e. Pakistan, Myanmar and Sri Lanka.

Implications/Originality/Value: Keeping in view the pace at which international and other concerned actors are inclined towards alliances formulation and militarization of the Indian Ocean Region, naval arms to acquire naval second strike capability is anticipated to be initiated in the near future, Indian ambitions to achieve the naval based second strike capability can be analyzed with the same lens.

(C)2021The authors, under a Creative Commons Attribution-

NonCommercial 4.0

Recommended citation: Latif, M. I. and Zia, M. T. (2022).Realignment of Power Patterns in Indian Ocean: Role of Regional and Global Actors. Journal of Business and Social Review in Emerging Economies, 7(4), 1029-1037.

\section{Introduction}

Indian Ocean has been evolving to be the arena for regional as well as global powers to pursue their respective national interests, considering the most significant energy trade Sea Lines of Communication. Subsidiary water bodies such as Persian Gulf, Gulf of Oman, Australian Bight, Mozambique Channel, Gulf of Aden, Java Sea, Savu Sea, Red Sea, Sea of Zanj, Andaman Sea, Flora Sea, Timor Sea and various other water channels and seas too are the offshoots of Indian Ocean. Security and stability of smooth functioning of its Sea Lines of Communication is the 
objective of all the concerned actors as any halt in maritime traffic would inflict devastating impact on regional and international actors (Shabbir, Bashir and Saleem, 2019: 48).

Moreover, Indian Ocean is having the most sensitive choke points on which various actors have divergent national interests. These choke points are:Strait of Hormuz, Strait of Malacca, Bab el Mandeb, Six and Ten Degree Channels, Mozambique Channel, The Sunda and Lombok strait.Strait of Hormuz is the connecting channel of Arabian Sea and Persian Gulf, which is between Oman and Iran. It is considered to be the hub of trading of crude oil as eighty five percent of Asian supply of crude oil is traversed in Strait of Hormuz and seventeen million barrel is transported on daily basis (Ahmad, 2015).

Strait of Malacca is one of the most crucial choke point in the Indian Ocean as it is the center of rift between India, US and China. It connects Indian Ocean with South China Sea and Pacific Ocean. East Asian states, Australia and China find the Strait of Malacca as the shortest oil import trade route through Persian Gulf. Beijing has vital concerns in this area as it is the backbone of China's oil imports and if it is blocked due to any reason, it would have direct and devastating impacts on its oil imports, ultimately on its economy.

Traditionally Indian Ocean region gained less attention in great power politics among various super powers i.e. during cold war era substantial focus was on Atlantic Ocean and Pacific Ocean by both of the super powers. But with the change in international strategic dynamics, Indian Ocean has evolved to be the central point of concentration of various regional and international actors. Historically, Indian Ocean remained eminent for oil trading, although this trait of Indian Ocean is still pertinent, yet shifting international patterns has compelled concerned players to engage in Indian Ocean politics other than oil trading. US, having the intentions to contain China, supports India in the region as New Delhi is the only viable regional option for the US to achieve the goal of containment of China (Lobo, 2021: 83). India on the other hand has the candidature of a more proactive role in Indian Ocean as its area of influence. Both Beijing and New Delhi are challenging each other in order to index themselves for the hegemony in Indian Ocean. To gain their objectives in the said maritime region Regional and international players are inclined towards the alliance formulation i.e. AUKUS, QUAD (Shah, 2021: 4).

Besides that notion of 'partnership' too is being advocated and practiced by China. Pakistan is affected too much in the wake of these developments as on the one hand Pakistan has severe maritime apprehensions regarding Indian Ocean due to growing disparity of naval powers between Pakistan and its arch rival India, and on the other hand in regional and international alignments US and other major relevant actors i.e. Japan, Australia, ASEAN have inclinations towards India. Moreover Pakistan is not a member of Indian Ocean Rim Association, in which India has a strong say. That has compelled Pakistan to be engaged in power politics of Indian Ocean Region and ultimately came closer to China. US Deputy Assistant Secretary, Bureau of East Asian and Pacific Affairs, Alex N. Wong stated that "it is in our interest, The US interest, as well as the interests of the region, that India plays an increasingly weighty role in the region. India is a nation that is invested in a free and open order". That has made evident that Washington has put the weight to New Delhi's side and Islamabad has left with no choice except to opt for the parallel power pole (Hassan, 2019: 79).

\section{US Interests in Indian Ocean}

The central principle of US foreign policy regarding Indian Ocean Region is that US cannot allow the emergence of a state or a coalition to be the decisive force in the region as that state or a coalition can potentially threaten the its national interests in entire Eurasian region. GeoEconomic shift of World towards Asia and subsequent growth of trade in Indian Ocean has enhanced the strategic significance of the area (Vaughn, 2018: 1). 
Since various past US administrations Washington had been pursuing the following national objectives in the Indian Ocean Region.

- It is one of the basic objectives of the US to counter piracy activities in the Indian Ocean Region.

- Maintaining and enhancing the prevalent dominant economic and strategic standing of the US in order to promote its economic interests there (Owais, 2020: 93).

- Support the like-minded partner states, India, Australia, Japan, to achieve the objectives of shared values and democracy.

- Security of significant strategic choke points of Indian Ocean such as Bab el Mandeb and Persian Gulf from terrorism (Vermeer, 2017: 6).

- Diminish or at least postpone the upsurge of larger scale conflicts i.e. Kashmir issue between Indian and Pakistan.

- To keep the check on proliferation of Weapons of Mass Destruction to any state actor or non-state actor.

- To keep the Sea Lines of Communication open in order to smooth flow of trade and naval patrolling in the Indian Ocean Region.

- To shape the strategic structure of Indian Ocean as required with the objective to prevent Asia dominated by a hegemon, be it a single state or be it a coalition which could threaten the interests of the US (Vaughn, 2018: 3).

US Naval Assets in Indian Ocean are as following.

1. A naval support facility of the US is positioned in Diego Garcia in South of India, a British Indian Ocean Territory. This facility is responsible for the logistic and operational support to the forward deployed forces generally in Indian Ocean and specifically in Persian Gulf Region (Harris, 2020: 1).

2. Camp Lemonnier Djibouti is considered to be the base for military, naval and logistic operations for Africa Command of the US in Horn of Africa. This facility serves 4000 civilian and Military personnel of the US as for as for the allied forces (Melvin, 2019: 21).

3. Naval Support Activity of Bahrain. This facility is the base for the US Fifth Fleet and the US naval Forces Central Command. This facility is responsible for the naval operational support to US Central Command Area of Responsibility (CENTCOM AOR). CENTCOM AOR covers Entire Middle East, Central Asia, Arabian Sea, Red Sea and Persian Gulf (Wallin, 2018: 1).

4. US Pacific Command Area of Responsibility (PACOM AOR) too covers a large area of Indian Ocean. Besides it under the domain of military alliance cooperation with Australia, US is having a rotational positioning of 2500 US marines and aircrafts around the Australia's Northern Coast, Darwin(Feickert,2013: 42).

\section{China's Interests in Indian Ocean}

China's core interest in Indian Ocean is the security of its energy supplies as being the largest energy consumer and China's economy is massively dependent upon its energy supply, it is its primary concern to eradicate every halt to Sea Lines of Communication in Indian Ocean. For that purpose it maintaining the adequate force in Indian Ocean is imperative for Beijing. It is evident from the Blue Book of China, which states that hedge against threats posed by other states, that Beijing is concerned about its vulnerabilities in Indian Ocean. Growing trade of China with Africa and Middle East needs China to have a more sophisticated position in Indian Ocean and for the very reason Beijing has increased its naval patrols in Indian Ocean and more specifically the strategic choke points of the region.

Statistics reveal that one third of international trade and shipping and $40 \%$ of international oil trade have to traverse Malacca Strait making it one of the busiest trade route. As far as China is 
concerned, significance of Strait of Malacca for Beijing is far more than any other concerned state. It is because more than $80 \%$ of China's energy supplies have to cross Malacca Strait (Akram, 2019: 34). Various challenges are faced by China in the said are such as piracy, Indian influence and US presence and a naval base in Singapore. Naval presence of the US in Malacca Strait inflicts two pronged impacts on China's in the Indian Ocean Region. On the one hand it is positively significant for China that US naval forces are stationed in Strait of Malacca with the objective of security of Sea Lines of Communication there. And on the other hand US naval facility is a matter of severe concern as for as Beijing's strategic interests in any event of confrontation in the region are concerned. The discussed Chinese vulnerability is catalyzed. Moreover, naval base of India in Andaman too is considered to be a challenge by Beijing (Sharif, R. 2015).

The term "Malacca Dilemma" was first coined by President of China Hu Jin Tao. Following that, China Youth Daily wrote that it is quite definite that whoever would govern Strait of Malacca would have the capability to influence the Sea Lines of Communication in the region. Various US analysts argue that any commotion in Sea Lines of Communications of Beijing's energy supply would have a more detrimental impact on China than any military attack on its territory (Ollapally, 2014: 348).

In the short-run contemporary maritime power pattern in Indian Ocean, it seems less likely that Beijing would opt for any confrontation with the US, Indian or other challenge. It is because of the US naval superiority and Indian strategic advantage. So it is anticipated that China would opt to a constructive engagement based on its 'harmonious sea' policy rather than to adopt an aggressive and offensive approach against India or the US with the objective to acquire more space in Indian Ocean. While on the long-run too, Chinese hostile and offensive role in Indian Ocean is not anticipated except that Beijing would seek more influence in the Indian Ocean Region with the increase in its economic power and military might in future (Hilali, 2014).

Beijing is now heading faster than expected by many scholars towards its increased economic as well as military and naval role in Indian Ocean Region. It may include the construction of naval and military bases alongside the Indian Ocean Littoral states. Ranging from developing a naval support base Djibouti to naval bases in Bangladesh and Sri Lanka, China has a variety of naval installations in Indian Ocean littoral states and this variability in size and function of these naval bases would serve in contingency plans i.e. non-combatant withdrawals, operations for antipiracy, protection of Chinese citizens, and even that any essential intervention in Indian Ocean littorals (Brewster, 2018).

To establish a strong foothold in the Indian Ocean Region, China has opted for various steps. Beijing has positioned its People Liberation Army Navy in Indian Ocean, for anticipatory operations. Submarines and ships of People Liberation Army Navy engaged in live-fire exercises in the said area to ensure its strategic objectives (Jash, 2021: 81). China has developed and ultimately acquired a strategically significant port in Sri Lanka, named Hambantota for a lease of 99 years. Located very close to India, the said port would assist China to, on the one hand China could have station its personnel at the port to support its cargo maritime transportation in any case of threat. And on the other hand, China may have a check on Indian maritime activities (Hassan, 2019).

China's traditional naval strategy had focused on near China Sea and Taiwan, but with the expansion of its interests and power around the globe, Beijing has shifted its concentration in far China Sea and "far China defense" too. The policy reveals the growing power and maritime interests of China as unlikely to previous decades, when China had a sole focus on South China Sea, in contemporary scenario growing Chinese concerns apart from its near seas and near 
neighborhood reflects the persistent growth in Chinese power. Li Keqiang China's Premier, justifies the sophistication of naval and military capabilities of China. He argued that it is because of the deep changes of security environment of China. Initial deployments of PLAN (People's Liberation Army Navy) in Indian Ocean were made with the objective of operations of antipiracy. With the passage of time Beijing enhanced the scope of its objectives in the Indian Ocean region, particularly securing its Sea Lines of Communication from its territorial waters to the Persian Gulf (O'Rourke, 2021: 1). China has significantly augmented its naval capabilities and patrolling in Indian Ocean as the number of Chinese warships has been increased from seven to fourteen in order to marginalize the US role and assert to be a leading regional and major global power (Gurung, 2017).

Despite of enhancing its footprints in Indian Ocean, Beijing still assumes its vulnerabilities in the Indian Ocean Region generally and in Strait of Malacca specifically. It is because of the strong say of the US together with its, US, naval base in Singapore. Moreover, Indian naval influence in the region too cannot be precluded as on the one hand India is the member of QUAD, which can influence the Chinese interests in the region to a significant extent and on the other hand Indian island of Andaman and Nicobar also are not too far from the strategically significant Strait of Malacca. Australia's inclusion in the Indian - led Malabar Naval Exercise together with US and Japan made it evident that the quadrilateral group is focusing on the naval influence in the region, which concerns China (Jash, 2021: 81).

In order to diversify the energy and other trade routes of China, CPEC is the most plausible option for Beijing in this regard. CPEC would be a two pronged alternative route for China as on the one hand China would bypass the Strait of Malacca and on the other hand CPEC would be the shortest logistic route for China, specifically for its South Western parts. Zhao Nanqi, former Director of Peoples Liberation Army's General Logistic Department once stated that Beijing would no more let Indians think as Indian Ocean to be the India's Ocean. Zhang Ming, naval expert of China is of the view that all the 244 islands which accumulatively named Andaman and Nicobar can be used to be the metal chain which may halt the Western part of the Strait of Malacca. Furthermore he stated that once New Delhi held its grip on Indian Ocean, Indian would not be confined to that extent rather it would keep on increasing its influence in the Indian Ocean Region (Hilali, 2014).

China's Far Sea Operations: Policy shift from near China Sea to Far Sea Operations manifest the Chinese concerns regarding the upper discussed views of Chinese officials. This Far Sea Operations is an Ocean Centric approach which is devised in order to secure the Sea lines of Communication utilized for the energy supplies of China. Since then Beijing is increasing its activity in the Indian Ocean along with South China Sea (Shabbir, Bashir, and Saleem, 2019: 48).

\section{Indian Ambitions in Indian Ocean}

India is the largest Indian Ocean Littoral state having the 7500 kilometers of coastline and 12 major ports and 200 minor sea ports along its coastline. Having such a huge maritime infrastructure is due to New Delhi's short-term and long-term maritime ambitions (Owais, 2020: 93). These Indian ambitions and hegemonic designs are the reason for which New Delhi is considering a more proactive role in the Indian Ocean Region. In the wake of 2013, some of the US Administration officials coined the terms i.e. "Indo Pacific", "Rebalance" "Indo-Asia Pacific" which is the signal that Washington is going to let India a more effective role in Indian Ocean (Jia, 2017: 2017).

In order to achieve its hegemonic designs in the said area India has adopted a multi-pronged approach which includes investments, diplomacy, trade, strategic partnership and sophisticated high seas naval patrols for which India requires a sea based second strike capability (Khan, 2016: 
155). New Delhi has acquired the discussed second strike capability but the development had inflicted deteriorated impacts as initiation of nuclear arm race in not only South Asian Region but also in the Indian Ocean Region. Although Indian hegemonic designs have gave birth to some serious issues of technical aspect and command and control system, yet taken together, New Delhi has gained the ground due to the rift between China and the US and their bilateral power competition. Even a step forward according to the J. Shankar, Indian Foreign Secretary, New Delhi aspires to be a leading power rather than just a balancing power (Tellis, 2016: 5).

Being a center-stage state in the Indian Ocean due to its ambitious hegemonic designs and largest Indian Ocean Littoral state, India is the one of the significant players in the maritime power politics of Indian Ocean Region. K. M. Pannikar, an Indian Diplomat is of the view that Indian lifeline is the subject to the Indian Ocean and Indian sovereignty is dependent upon the waters of Indian Ocean. According to him India cannot excel in any mechanical development or business progression and no political or economic arrangement in India would be fruitful if its seashores are vulnerable (Khan, 2016: 156).

In order to have a strong say in Indo Pacific, in Indian Ocean too, New Delhi in 1990 took a foreign policy step named "Look East" by the Government of NarshimaRao. Look East policy intended to augment trade and economic relations with the states in East Asia. Besides the economic and trade ties, strategic advantage too is the key element behind this policy. Some of the key intentions of Look East are as

- Indian strategic interests are subject to the strength of the Indian Navy and this policy would enhance the Indian naval capabilities.

- In order to shrink the growing Chinese influence in the region, New Delhi must have constructive relations with the East Asian nations (Shabbir, Bashir and Saleem, 2019: 53).

New Delhi's strategic partnership with Tehran is a crucial development in Indian Ocean power politics. Iran's close proximity to Strait of Hormuz provides it a great leverage of a proactive role in Indian Ocean Region, specifically the world oil trading. Although Iran has demonstrated some inclination towards China, yet India is one of the top list importers of Iranian oil products and both of the actors, Tehran and New Delhi, are in a bilateral strategic agreement. India has supported Iran in sophistication of Chahbahar port which is near Farzad oil fields. Despite of sanctions imposed on Iran by the US, Washington have offered a waiver for New Delhi for latter's oil imports from Iran, which reveals the depth of Indo-US close ties in the region (Hassan, 2019: 80).

Furthermore, in addition from the significance for India due to oil trading, New Delhi can monitor the naval activities of China and Pakistan while stationed in Iran, which is a at least a concern, if not threat, for both of the latter states. In order to achieve and augment this objective, New Delhi took over the Duqm port of Oman to provide the logistic and maintenance assistance to its naval ships in Indian Ocean. Apart from that this port would provide India with a swift access to Gulf of Aden and Red Sea and formulation of new Sea Lanes of Communication in Indian Ocean (Hassan, 2019: 83).

\section{Pakistan's Concerns in Indian Ocean}

Having the coastline of $1050 \mathrm{KM}$ and extensive dependence upon Indian Ocean regarding its economic and trade functions, Pakistan is considered to be the major littoral state of Indian Ocean. A significant part of oil imports and more than ninety percent of global trade of Pakistan relies on Indian Ocean. Major part of these activities is operated at the Karachi port, which is vulnerable to the multiple emerging threats in Indian Ocean, particularly by Indian naval ambitions. Islamabad has not put the adequate focus on its maritime power as it needed to be. 
Maritime anxieties of Pakistan are at their core Indian centric. It is because in any act of war or naval clash, Indian naval dominance over Pakistan may consequently lead towards the barricade of Karachi, which may cause the crushing damages to latter's economy and naval and strategic standing in the region. Increasing disparity of naval conventional power between both of the South Asian players has led New Delhi on strategic advantage. Subjective naval advantage that Islamabad enjoyed till 1990s was over taken due to US sanctions against Pakistan during the said decade. During that time frame, New Delhi quantitatively and qualitatively enhanced its naval capabilities. Ambitions of New Delhi to acquire naval based second strike capability have hampered the naval balance in the Indian Ocean Region. Considering the debates of anticipations of a low or a large scale armed clash between New Delhi and Islamabad cannot be completely discarded, so extensive naval disparity between India and Pakistan may result into instability of the region (Khan, 2016: 155).

In order to avoid that environment and balance the strategic alignment, CPEC would assist to strengthen Pakistan's position in the region. Although economic aspect of Gwadar port and CPEC is evident yet various factors throttle its vitality. But its potential to strengthen the strategic position and security of Pakistan's struggling maritime standing as well as defense of its land borders (Pande: 2015).

Geostrategic position of Gwadar port could assist Pakistan to have a listening post in Indian Ocean just at the brink of hub of oil trading maritime Sea Lanes of Communication and monitoring of maritime traffic. Various defence analysts in Pakistan have the perspective that development of Gwadar port would solidify Islamabad's bargaining position in the Indian Ocean maritime affairs while negotiating with the concerned regional and international actors (Kaleem, 2018: 112). Moreover in any event of naval confrontation, Gwadar would be a strategic asset for Pakistan than heavily vulnerable port of Karachi. While considering the alliances formulation i.e. QUAD, AUKUS and other Indo-US naval collaborative activities, CPEC and Gwadar port would help China and Pakistan to boost their naval exercises and naval cooperation in Indian Ocean as a counter weight (Butt and Butt, 2015: 30).

Operationalization of Gwadar port and its inclusion, to be the hub, in Belt and Road Initiative would marginalize the previously discussed Indo-Iran strategic ties, for the reason that Belt and Road Initiative is anticipated to have the potential to transform the geo-economic and geostrategic patterns not only in the Indian Ocean Region but globally as well. And Tehran has expressed its interest to be the part of that project. In addition to the potential of Gwadar to restructure the power equation in Indian Ocean, the said project would be a deterrent to New Delhi for its support of insurgency in Baluchistan. It is because of the presence of Chinese interests and installations in Baluchistan would daunt India for its support to terrorism in the province (Wagner, 2016: 2).

\section{Conclusion}

Indian Ocean Region is gravity of power projection is increasing with the time. Various regional and international actors are shifting their focus in the said region. Indian Ocean region is being contested by China and India to be their area of influence. Geographically India is the only state which is, and can, confronting China, and in order to achieve this objective India has found US, Australia and Japan on the same page. Therefore, all of these states are inclined towards formulation of alliances i.e. QUAD, AUKUS and bilateral strategic agreements. Beijing has taken a series of steps in order to balance the power equation such as the economic partnerships and deploying its naval installations in various ports, i.e. Djibouti and Sri Lanka. Being a key littoral state of Indian Ocean and vulnerable to the increasing tensions and militarization of the Indian Ocean Region, Pakistan is compelled to be the part, not party, of power politics of Indian Ocean. By joining Belt and Road Initiative and having proximity to Strait of Hormuz via 
Gwadar, Pakistan has made attempts to marginalize Indian maritime hegemonic designs in Indian Ocean.

\section{References}

Ahmad, Z. (2015). 'China-Pakistan Economic Corridor: a vital component of emerging strategic significance of Indian Ocean'. Proceedings of International Conference on CPEC, GC University, Lahore. Retrieved from https://ps.gcu.edu.pk/piccpec.

Akram, Q. (2019). 'China's Malacca Dilemma: Power Politics in Indian Ocean'. Journal of Politics and International Studies. Vol. 5(2). pp. 29-44. Retrieved from https://www.academia.edu/41582195/Chinas_Malacca_Dilemma_Power_Politics_in_Ind ian_Ocean

Butt, K. M., and Butt, A. A. (2015).'Impact of CPEC on regional and extra regional actors'. Journal of Political Science.(33). pp. 23-44. Retrieved from https://ps.gcu.edu.pk/wpcontent/uploads/2015/02/Butt-Butt.pdf.

Brewster, D., (2018). 'Welcome to the new Indian Ocean'. The Diplomat. Retrieved from http://thediplomat.com/2018/02/welcome-to-the-new-indian-ocean/.

Feickert, A. (2013). 'The unified command plan and combatant commands: background and issues for Congress'. Congressional Research Services. Retrieved from htps://crsreports.congress.gov/product/pdf/R/R42077/11.

Gurung, S. K. (2017). '14 Chinese naval ships spotted in Indian Ocean, Indian Navy monitoring Locations'.The Economic Times. Retrieved from https://m.economictimes.com/news/defence/14-chinese-naval ships-spotted-in-indianocean-indian-navy-monitoring-locations/articleshow/61882634.cms.

Harris, P. (2020). 'A footprint of unfreedom: The future of naval support facility Diego Garcia'. Journal of Indo-Pacific Affairs. pp. 78-97. Retrieved from https://media.defense.gov/2020/Jun/08/2002311975/-1/-1/1/HARRIS.PDF

Hassan, M. A. (2019). 'Growing China-India Competition in the Indian Ocean'. Institute of Strategic Studies Islamabad. Vol. 39(1). pp. 77-89. Retrieved from https://www.jstor.org/stable/10.2307/48544289.

Hilali, A. Z. (2014). 'Contemporary geo-politics of Indian Ocean and great power competition over Gwadar'. Paper presented at The International Conference on- Major Powers' Interests in Indian Ocean: Challenges and Options for Pakistan. Serena Hotel, Islamabad. Retrieved from https://ipripak.org/major-powers-interests-in-indian-oceanchallenges-and-options-for-pakistan/.

Jash, D. A. (2021). 'The QUAD factor in the Indo-Pacific and the role of India'. Journal of IndoPacific Affairs. pp. 78-85. Retrieved from https://www.airuniversity.af.edu/JIPA/Display/Aerticle/2528182/the-quad-factor-in-theindo-pacific-and-the-role-of-india/.

Jia, C. (2017). 'New trends of US policy towards South Asia: challenges to CPEC'. Islamabad Policy Research Institute. Vol. 7(1). pp. 95-121.

Kaleem, I. (2018). 'Geo-strategic prospects of Gwadar Port: an analysis of protecting sea lanes of Indian Ocean'. Journal of Political Studies. pp. 111-120. Retrieved from http://pu.edu.pk/images/journal/pols/pdf-files/9_spec_18.pdf.

Khan, S. (2016). 'India's Quest for hegemony in the Indian Ocean'. Journal of Security and Strategic Analysis. Vol. 2(1). pp. 144-164. Retrieved from https://www.proquest.com/docview/2424658208.

Lobo, J. S. (2021).'Balancing China: Indo- US relations and convergence of their interests in the Indo-Pacific'. Journal of the National Maritime Foundation of India. pp. 73-91. Retrieved from https://doi.org/10.1080/09733159.2021.1952618

Melvin, N. (2019). 'The foreign military presence in the Horn of Africa Region'. SIPRI Background Paper. Retrieved from https://sipri.org/sites/default/files/201904/sipribp1904.pdf. 
Ollapally, D. M., (2014). 'China and India: economic ties and strategic rivalry'. Foreign Policy Research Institute. p.342-357. Retrieved from https://www.fpri.org/article/2014/07/china-and-india-economic-ties-and-strategicrivalry/.

O'Rourke, R. (2021). 'China Naval Modernization: Implications for U.S. Navy CapabilitiesBackground and Issues for Congress'. Congressional Research Service. Retrieved from https://fas.org/sgp/crs/row/RL33153.pdf.

Owais, M. (2020). 'Indian Ocean and Indo-China rivalry: challenges for Pakistan'. Journal of Indian Studies. Vol. 6(1). pp. 91-100 Retrieved from http://pu.edu.pk/home/journal/44/v6_no1_20.html.

Pande, S. (2015). 'Sino-Pak strategic relationship: Implications for India. Centre for Land WarfareStudies'. $\quad$ pp. 18-24. $\quad$ Retrieved from https://archive.claws.in/images/journals_doc/1942499114_SinoPakStrategicRelationship. pdf.

Shabbir, M. O., Bashir, R. and Saleem, S. (2019). 'Geo- Strategic importance of Indian Ocean: clash of interests between China and India'. Journal of Indian Studies. Vol. 5(1). pp. 4760. Retrieved from https://www.ipindexing.com/journal-article/Geo-Strategic-Imprtanceof-Indian-Ocean-clash-of/22097.

Shah, R. (2021).'Pakistan's quest for balance in the context of Indo- Pacific strategy'. Australian Journal of Maritime and Ocean Affairs. pp. 1-14 Retrieved from https://doi.org/10.1080/18366503.2021.1925467.

Sharif, R. (2015).'Maritime challenges of China's trade routes- Chinese rationale for undertaking CPEC'. Proceedings of International Conference on CPEC, GC University, Lahore. Retrieved from https://ps.gcu.edu.pk/piccpec.

Tellis, A. J. (2016). 'India as a leading power'. Carnegie Endowment for International Peace. Retrieved from https://carnegieendowment.org/files/CP_268_Tellis_India_final1.pdf.

Vaughn, B. (2018). 'China- India great power competition in the Indian Ocean Region: Issues for Congress'. Congressional Research Service. Retrieved from https://www.everycrsreport.com/reports/R45194.html.

Vermeer, M. (2017). 'Maritime power politics in Indian Ocean region (IOR)'.ISPSW Strategy Series. pp.1-9. Retrieved from https://ethz.ch/content/dam/ethz/specialinterest/gess/cis/center-for-securities-studies/resources/docs/ISPSW$519 \% 20$ Vermeer.pdf.

Wagner, C. (2016).'The effects of China- Pakistan Economic Corridor on India- Pakistan Relations'. German Institute for International and Security Affairs. pp. 1-4. Retrieved from https://www.swp-berlin.org/en/publication/effects-of-the-china-pakistan-economiccorridor-on-india-pakistan-relation.

Wallin, M. (2018). 'U.S. military bases and facilities in the Middle East'. American Security Project. Retrieved from https:/www.americansecurityproject.org/wpcontent/uploads/2018/07/Ref-0213-US-Military-Bases-and-Facilities-Middle-East.pdf. 